\title{
Settlement patterns of red and purple sea urchins (Strongylocentrotus franciscanus and S. purpuratus) in California, USA
}

\author{
Thomas A. Ebert ${ }^{1}$, Stephen C. Schroeter ${ }^{1}$, John D. Dixon ${ }^{1}$, Peter Kalvass ${ }^{2}$ \\ ${ }^{1}$ Department of Biology, San Diego State University, San Diego, California 92182-0057, USA \\ ${ }^{2}$ California Department of Fish and Game, 19160 S. Harbor Drive, Fort Bragg, California 95437, USA
}

\begin{abstract}
Weekly settlement of red and purple sea urchins (Strongylocentrotus franciscanus and S. purpuratus) was documented at sites in northern and southern California (USA) for 4 settlement seasons from 1990 to 1993 . Newly settled sea urchins $(<0.5 \mathrm{~mm})$ were collected from standardized settlement surfaces (scrub brushes), identified and counted. There was marked seasonality in settlement. For both species, most settlement occurred during one to several episodes between February and July of each year. Settlement tended to be more regularly annual in southern than in northern California and settlement densities generally were higher in the south. This pattern is consistent with greater retention of water in the Southern California Bight and more energetic offshore advection of water in northern California. S. purpuratus showed geographic coherence in settlement whereas $S$ franciscanus did not. For purple sea urchins, northern sites formed a group, a second group was formed by sites near Santa Barbara plus a site in Orange County, and a third group was formed by 3 sites at San Diego.
\end{abstract}

KEY WORDS: Echinodermata - Echinoidea - Sea urchin - Settlement

\section{INTRODUCTION}

The term 'metapopulation' was coined by Levins (1969) to mean a population of populations and is well suited to describe benthic marine organisms with planktonic stages (e.g. Roughgarden et al. 1988, Botsford 1992). For such species, there are local populations where individuals interbreed but the products of fertilization may be carried great distances before settlement occurs (cf. Scheltema 1971, 1986). In the case of red and purple sea urchins (Strongylocentrotus franciscanus and $S$. purpuratus), the geographic range of each species spans about 30 degrees of latitude from Alaska to Cedros Island in Baja California, Mexico. In any local population, adults probably move no more than tens or hundreds of meters during a lifetime; however, larvae of these species feed in the plankton for at least $5 \mathrm{wk}$ before they are competent to settle (R. Strathmann 1978, Cameron \& Schroeter 1980. Leahy 1986, M. Strathmann 1987, Rowley 1989) and so may be carried hundreds or perhaps thousands of kilometers from their sources.

Along the California coast, the driving physical force in the transport of planktonic larvae generally is agreed to be the southward directed California Current and associated counter-currents (Mackas et al. 1992). The strong prevailing southward winds north of Point Conception generate intense upwelling (Huyer 1983) and the region is considered to have offshore transport of pelagic larvae (Parrish et al. 1981). A complicating factor is the energetic offshore advection of water at major headlands in northern California and Oregon, which may result in poor larval settlement (Ebert \& Russell 1988).

South of Point Conception, the coastline bends to the east and then south forming the Southern California Bight. Wind stress is much less than it is farther north, local upwelling is weaker and generally confined to spring and summer, and there is less mixing of the water masses (Halliwell \& Allen 1987, Mackas et al. 
1992). The California Current flows south from Point Conception and bends eastward back towards the coast at about $32^{\circ} \mathrm{N}$ (Lynn \& Simpson 1987), which creates a gyre or eddy with water flowing northwestward off the coast back towards Point Conception. Northward flow within the Bight is most apparent in late spring/early summer and again in the fall (Thomas \& Strub 1990).

In addition to the large-scale oceanographic differences between northern and southern California, there are notable changes in marine benthic communities. The northern or southern extreme in the geographic range of many invertebrate species occurs near Point Conception and there is a striking difference in the relative abundance of many intertidal species at mainland sites within the Southern California Bight compared to sites on the northern Channel Islands and central California (Morris et al. 1980, Seapy \& Littler 1980). Although red and purple sea urchins are abundant at both northern and southern sites, there are suggestions that their population dynamics differ regionally. Recruitment of juveniles of both species (generally based on size distributions) has been described as occurring in infrequent pulses in northern California, Oregon, Washington and British Columbia (Ebert 1968, 1983, Bernard \& Miller 1973, Paine 1986, Pearse \& Hines 1987, Sloan et al. 1987) and more regularly seasonal or continuous in southern California and Mexico (Pearse et al. 1970, Tegner \& Dayton 1981, Ebert 1983).

The regional physical and biological differences along the west coast indicate that red and purple sea urchins may form more than a single metapopulation. Understanding the population dynamics and evolution of such species requires estimating rates of interchange among units of the metapopulations through larval dispersal. This, in turn, requires knowledge of coastal and offshore physical and biological oceanographic processes between the times of spawning and settlement as well as information on early survivorship to the size or age of reproduction. The task is neither simple nor straightforward.

We focus here on one piece of the puzzle by documenting the patterns of settlement of red and purple sea urchins at sites in northern and southern California over 4 settlement seasons. Estimating actual settlement provides a touchstone for judging the relative importance of post-settlement survival and growth in determining the size structure of populations and their inferred recruitment patterns. For example, the apparent differences in recruitment in northern and southern California may reflect regional differences in early mortality and growth rather than characteristic differences in settlement. On the other hand, consistent large-scale spatial differences in settlement may indicate that larval exchange generally is constrained by physical oceanographic processes. These geographic units would be the logical places to look both for explanatory oceanographic characteristics and for the differences in the genetic structure of sea urchin populations that would be expected to arise from limited larval exchange.

\section{METHODS}

Settlement collectors. Documenting settlement required developing suitable collectors and we are by no means the first to do this for echinoderms. Loosanoff (1964) used oyster shells as collectors to study settlement of the starfish Asterias forbesi on the Atlantic coast of the U.S. For sea urchins, collectors of various designs using rigid plastics have been used extensively by the Japanese (Dept of Mariculture, Hokkaido 1984; also see Tegner 1989). Bak (1985) constructed collectors from plastic light diffusers ('egg crate'), a precursor of the collectors constructed by Harrold et al. 1991), and we have used panels of fiberglass roofing and artificial grass (Astroturf ${ }^{\mathrm{TM}}$ ) (Ebert et al. 1991).

In work presented here, we selected scrub brushes with nylon bristles (\#0115, National Brush Company, Aurora, IL, USA) as our collectors based on a preliminary test of 3 brush types in 1988 (Ebert unpubl.). A \# 0115 brush has a $6 \times 9 \mathrm{~cm}$ wooden base with $2.5 \mathrm{~cm}$ nylon bristles. These brush collectors have a major advantage over sea urchin collectors that have been used by other investigators (Dept of Mariculture, Hokkaidō 1984, Bak 1985, Harrold et al. 1991) in not requiring special fabrication. Also, brushes are cheap and provide convenient replication of collector surfaces.

Brushes were attached to nylon lines and suspended in the water column from piers or from overhanging ledges from shore or were anchored to the bottom at offshore sites. Two lines were deployed at each site and each line held 4 brushes, giving a total of 8 brushes per site. On each line, the first pair of brushes was about $1 \mathrm{~m}$ from the bottom and the second pair was about 20 to $40 \mathrm{~cm}$ above the lower set. A groove was cut into the back of each brush that allowed it to fit snugly around the line and pairs of brushes were held in place with nylon cable ties (Fig 1). The line was knotted or wrapped with cable ties to prevent the brushes from moving up or down. When lines were attached to a pier or overhanging cliff from shore, a 4 to $5 \mathrm{~kg}$ weight was attached to the bottom of the line. For offshore stations, the bottom of the line was attached to an 18 to $20 \mathrm{~kg}$ steel weight and suspended in the water column with a small subsurface float. Brushes were collected each week and replaced either 
Fig. 1. Detail of settlement collectors (wood-handle scrub brushes) held to a nylon line with plastic cable ties

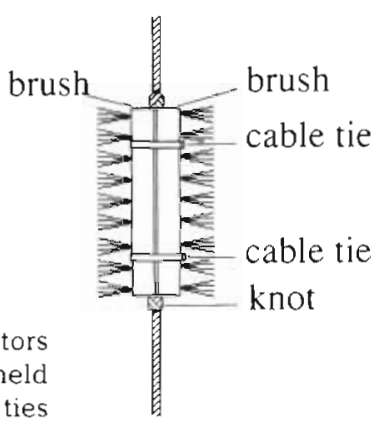

with new brushes or with brushes that had been collected the previous week and had been rinsed in fresh water. Following collection, brushes were placed in individual plastic bags and transported to the laboratory in an ice chest.

A sonic cleaner was used to remove animals from brushes. A brush was placed, bristle side down, in the cleaner with seawater and sonicated for 3 to $5 \mathrm{~min}$ During sonication the bristles were occasionally rubbed by hand in order to help free animals that might have been hidden deep within a bristle cluster. Following sonication, the water was poured into a large plastic cup that had $0.436 \mathrm{~mm}$ mesh plastic screen on one side, which is sufficiently small to retain newly settled sea urchins. Material retained in the cup was sorted under a dissecting microscope and all sea urchins were identified at once and then preserved, or were preserved in $70 \%$ ethyl alcohol for later identification to species. Identification of newly settled sea urchins to species was based on the presence of dorsal pedicellariae and pigmentation. Strongylocentrotus purpuratus lacks dorsal pedicellariae and $S$. franciscanus has from 1 to 3 (Rowley 1989). In southern California another local species, Lytechinus anamesus (=pictus), also has dorsal pedicellariae but is less pigmented than $S$. franciscanus.

Sites and sampling schedule. In 1990, sites were selected in northern and southern California (Fig. 2). Site selection was determined by accessibility under most weather conditions, as well as availability of persons to tend the collectors. In northern California collectors were deployed: (1) off a rock overhang from shore at Westport; (2) off a rock overhang from shore at Point Cabrillo; and (3) from the pier at Arena Cove south of Point Arena. In southern California collectors were deployed: (4) off Gaviota Pier, which is south and east of Point Conception; (5) off Ellwood Pier near Goleta; (6) from Stearn's Wharf at Santa Barbara; (7) offshore from Dana Point in southern Orange County, (8) from the pier at Scripps Institution of Oceanography in La Jolla; (9) off Ocean Beach Pier in San Diego; and, (10) offshore from Point Loma in San Diego.
Settlement, or 'weekly recruitment', was monitored for different lengths of time at different sites. Westport, Point Cabrillo, Ellwood Pier, Dana Point, Scripps Pier, and Ocean Beach Pier were monitored from February/March 1990 through July 1993. Collectors off Point Loma were tended from March 1990 through summer 1992. Settlement collectors were tended at the pier at Arena Cove from March 1990 until the beginning of April 1991. Stearn's Wharf and Gaviota Pier were monitored from January and February 1991 through summer 1993. Some gaps occur in the data sets due to vandalism, a sewage spill off Point Loma, rig losses caused by swell conditions, storms that prevented retrieval of collectors, and scheduling conflicts of our various volunteer groups.

Analysis. In our analyses, we used both the numbers of recently settled individuals and the variation in numbers. Estimates of the coefficient of variation [(standard deviation/mean) $\times 100 \%$ ] for red and purple sea urchins were grouped by species and geographic area (north or south of Point Conception), and the groups tested by a 2-way ANOVA to determine whether annual variability was different for the 2 species inside and outside the Southern California Bight; that is, Areas II and III in the classification of Mackas et al. (1992). A preliminary analysis showed no significant interaction of species $x$ area and so the ANOVA was done without interaction.

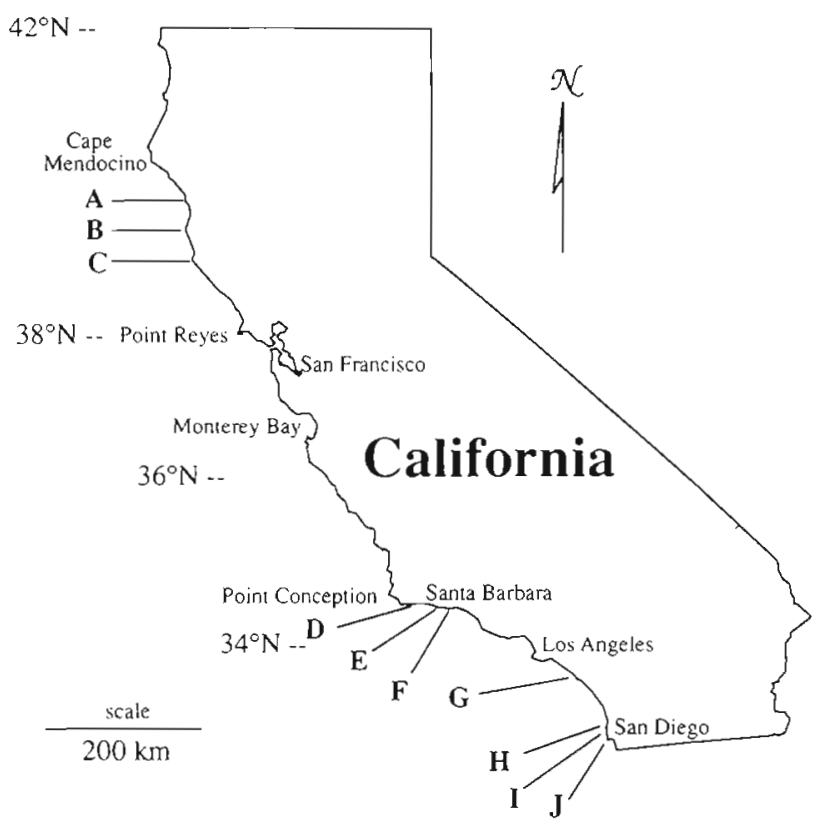

Fig. 2. Location of sites in California, USA, where settlement was measured. A: Westport; B: Point Cabrillo; C: Arena Cove D: Gaviota; E: Ellwood Pier; F: Stearn's Wharf; G: Dana Point; $\mathrm{H}$ : Scripps Institution of Oceanography; I: Ocean Beach; $\mathrm{J}$ : Point Loma 
Geographic coherence was examined using the VARCLUS procedure (SAS Institute 1988), a divisive clustering technique that attempts to divide a set of variables into non-overlapping clusters. The analysis begins with a matrix of correlations between all pairs of stations. The variate used to calculate the correlations was the average number of settlers per brush for each week. If the period between samples was more than $7 \mathrm{~d}$, the number per brush was standardized to a week. Given the matrix of correlations, the analysis split the data into 2 clusters by finding the first 2 principal components, and assigning each station to the rotated component with which it had the higher squared correlation. Stations were iteratively reassigned to clusters to maximize the variance accounted for by the cluster components. Of the resultant clusters, the one with the largest eigenvalue for the second principal component was selected, and the splitting procedure repeated. The analysis was halted when each cluster had only a single eigenvalue greater than 1. Because new stations were added in 1991 and 1 station (Point Loma) was dropped in 1993, the clustering analysis was done for each species for several time periods: 1990-1992, 1990-1993, 1991-1992, and $1991-1993$.

\section{RESULTS}

Settlement was strongly seasonal for red and purple sea urchins in both northern and southern California (Figs. 3 to 8); however, there was substantial variability in the number of settlers both from site-tosite within years and from year-to-year within sites (Table 1). Although the settlement season was similar at all the study sites, the Califormia coast was not a single coherent unit with respect to the pulses of settlement.

The general settlement patterns we observed from 1990 to 1993 for both species showed year to year variation around late winter to early summer events in both southern and northern California. Across years, there was variation in length of the settlement season: generally longer in 1992 and shorter in 1993. Even where some settlement occurred during all seasons of the year, such as Strongylocentrotus purpuratus at Gaviota during 1991 and 1992, there was a recognizable pulse in the spring (Fig. 4).

Total annual settlement, from late December through mid December, varied from year to year (Table 1). Of particular interest is the difference in variability across sites (Fig. 9). Annual totals at northern sites (Table 2) were significantly more variable across years than southern sites $(p=0.005)$ and annual totals for Strongylocentrotus franciscanus were significantly more variable across years than totals for $S$. purpuratus $(\mathrm{p}=0.030)$. There also is an indication of a temporal trend for both species across years (Table 1) with annual settlement generally declining over the years in southern California and generally increasing in northern California. This perception is based on generally negative correlations of total numbers versus years south of Point Conception and the positive trend at Point Cabrillo (Fig. 3). Missing data from February through April 1993 at Westport compromise the northern data set and an ANCOVA with year as a covariate failed to show a significant difference in slopes between northern and southern California. The data are not up to a rigorous analysis of the trend.

There also were very local patterns in the data. For example, settlement of Strongylocentrotus purpuratus at Scripps Pier in 1990 was much greater than in 1992 yet settlement at Ocean Beach was about the same for these 2 years and at Point Loma there were fewer settlers in 1990 than in 1992. In northern California, settlement occurred in June/July 1993 at Point Cabrillo but no settlers were found during the same period at Westport. Only $2 S$. franciscanus were collected at Ocean Beach Pier from 1990 to 1993 but many more were collected at stations on either side (Scripps Pier to the north and Point Loma to the south).

The clustering patterns shown by Strongylocentrotus purpuratus (Fig. 10) for 4 different time periods all are similar and clustering accounts for a substantial amount of the total variance in settlement patterns. The smallest proportion of explained variance is 0.65 for the 3 clusters formed for 1991-1993; all other clusterings, 1990-1992, 1990-1993, and 1991-1992, explain between 74 and $77 \%$ of the variation. Three southern California sites, Point Loma, Ocean Beach Pier, and Scripps Pier, all cluster together. Settlement patterns at sites near Santa Barbara, Ellwood Pier, Stearn's Wharf, and Gaviota Pier all cluster together with the settlement pattern at the site offshore from Dana Point. Northern sites, Point Cabrillo and Westport, form a cluster. A curious feature is that settlement patterns of $S$. purpuratus in northern California are more like the patterns near San Diego than like the patterns off Santa Barbara, which is geographically closer to northern California.

Unlike Strongylocentrotus purpuratus, the clusters for $S$. franciscanus did not form contiguous geographic subunits (Fig, 11). This result could reflect a real pattern of greater spatial as well as temporal variability in S. franciscanus; alternatively, it may have been the result of lower levels of settlement and the consequent inability of the analysis to detect an underlying geographic signal. 

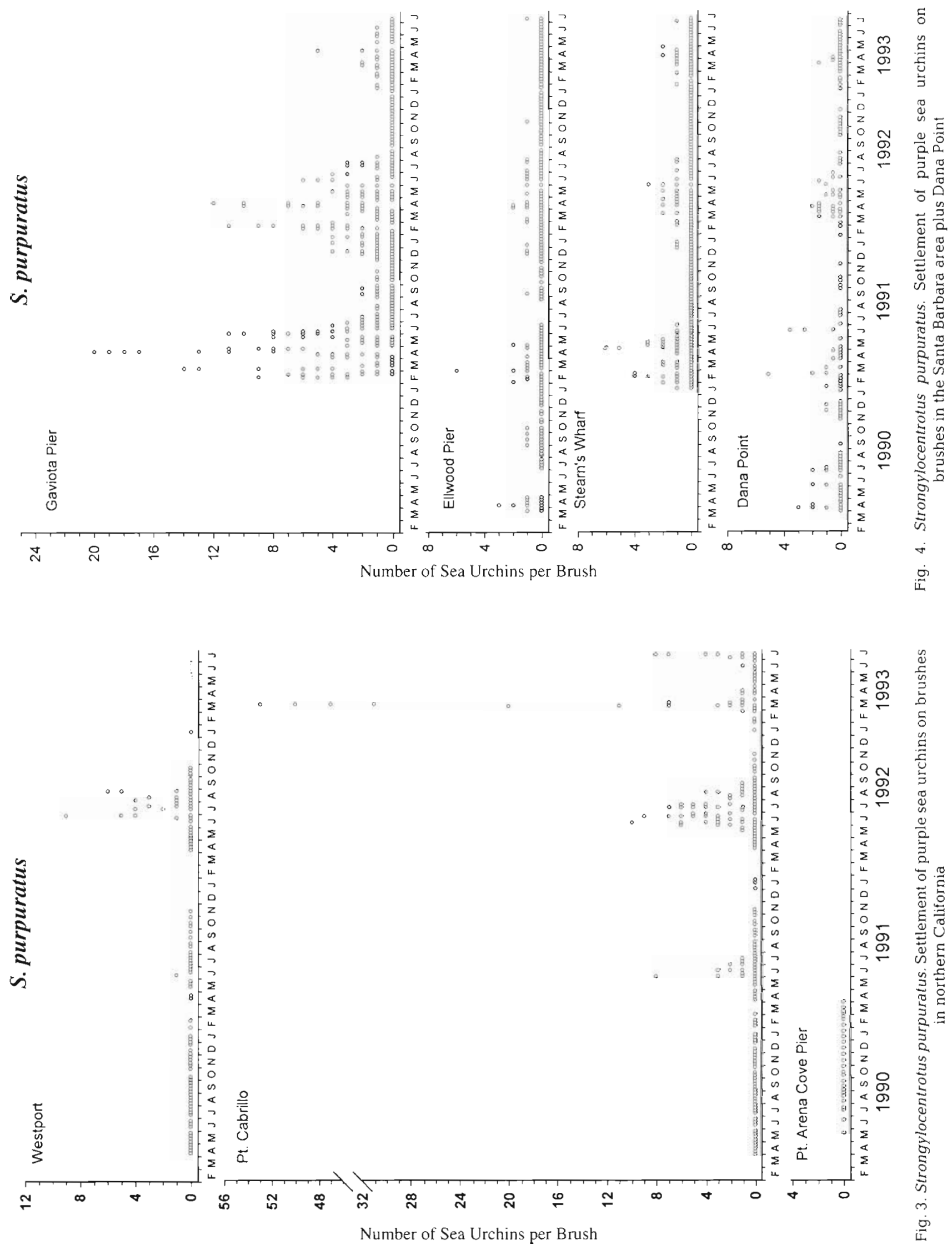

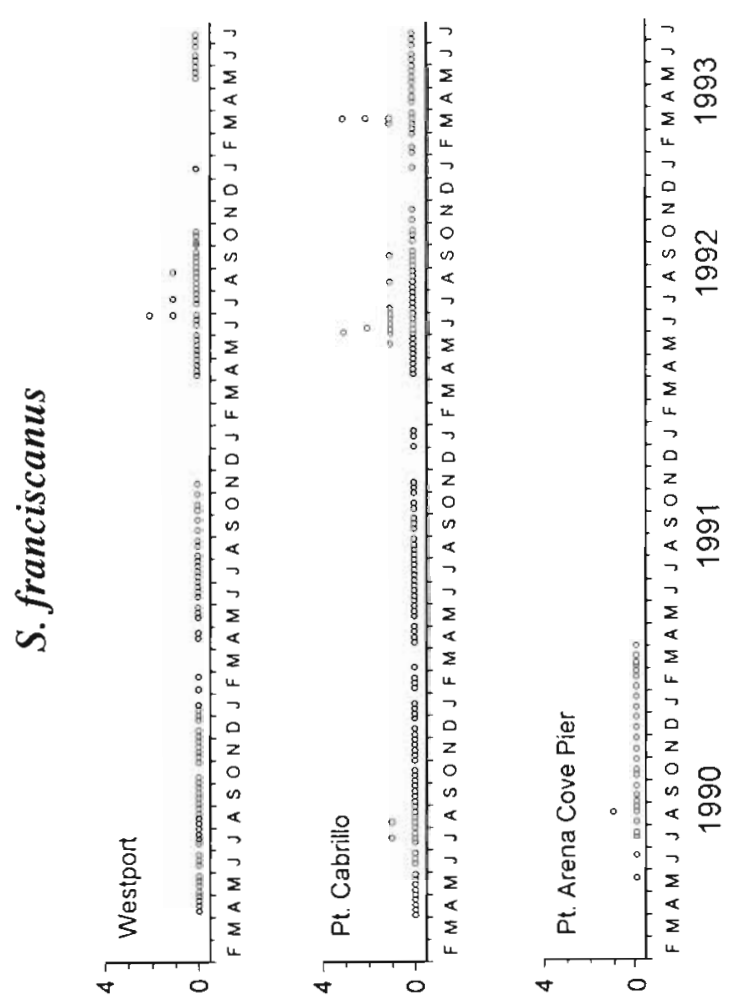

ร

Number of Sea Urchins per Brush

\section{DISCUSSION}

Most settlement of both red and purple sea urchins occurred during one to several episodes of varying duration between January and August of each year. Although there was a tendency for most settlement to take place in late winter to spring in the south and in summer in the north, there was substantial variability. For example, the largest pulse of settlement we observed at a northern site was at Point Cabrillo in March 1993 and, at southern sites near San Diego in 1992, most settlement was observed in June and July. There also was occasional settlement during the fall or winter in southern California, especially at Dana Point and Gaviota Pier.

Harrold et al. (1991) monitored collectors monthly from mid 1988 to mid 1989 (1 yr) at a site near Monterey (see Fig, 1 for location) and found recently settled Strongylocentrotus spp. every month except October. However, peaks of recruitment were observed from December through February and during June and July. The December to January pulse they report is earlier than any settlement we observed in the Fort Bragg area, which may reflect normal small-scale spatial variability or temporal variability similar to that which we observed in our study rather than character-
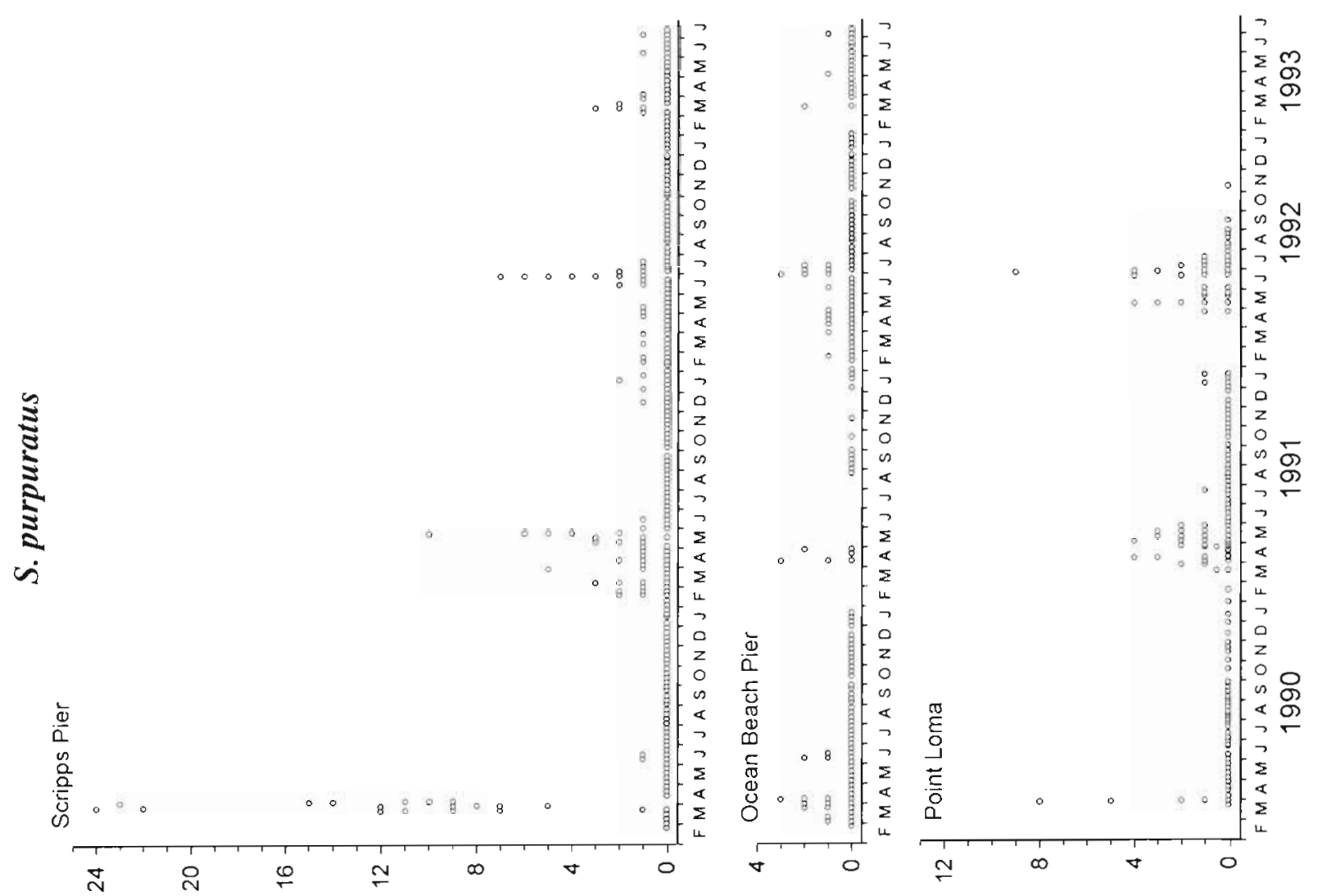

Number of Sea Urchins per Brush 

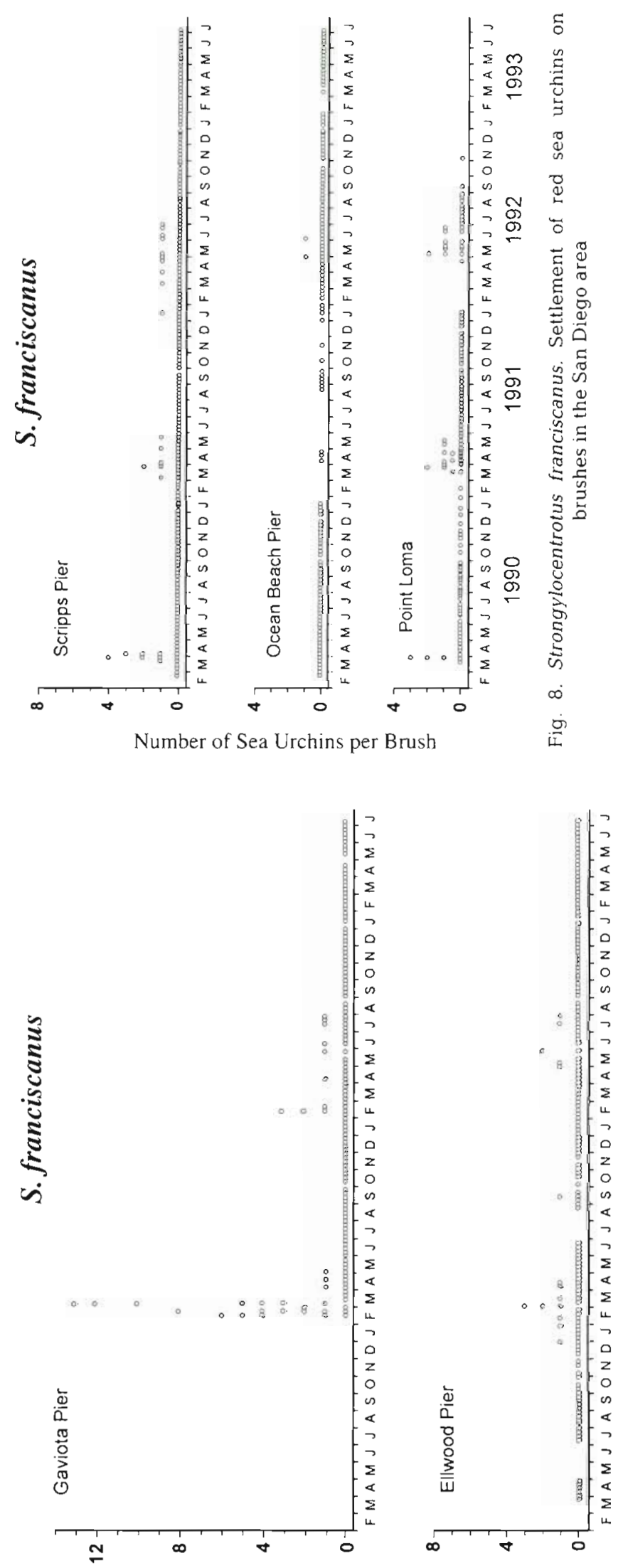

istic differences between central and northern California. At Naples Reef near Santa Barbara, Rowley (1989) sampled very small Strongylocentrotus spp. from 1984 to 1986 and, during that period, he observed a single pulse of recruitment in May 1986. By comparing size ranges in the field with those obtained under laboratory conditions, he inferred that animals in the field were from 5 to $17 \mathrm{~d}$ old, which makes the settlement season similar to the settlement times we observed in the Santa Barbara area.

Temporal and spatial differences in settlement of red and purple sea urchins correlate with general oceanographic processes along the California coast. Annual settlement of both species was more variable in the north, which correlates with the retention of water within the Southern California Bight and greater advection rates in northern California (Owen 1980, Parrish et al. 1981, Huyer 1983, Kosro et al. 1991). There was virtually no settlement of sea urchins at the northern sites in 1990 and the average number of settlers was low in 1991; however, in each of the next 2 years, large numbers of purple sea urchins settled and red sea urchin settlers were present in low to moderate numbers. This change in settlement pattern coincided with an El Niño event that started late in 1991 and continued through the 1993 settlement season (Hayward
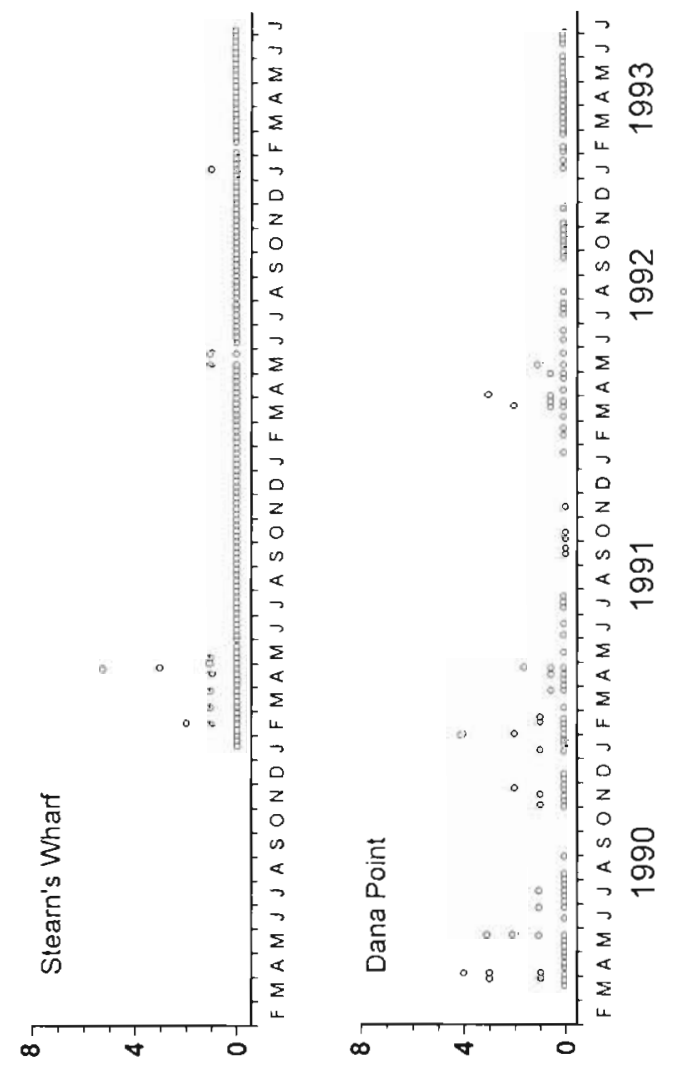

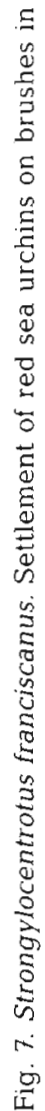

Number of Sea Urchins per Brush 
Table 1 Strongylocentrotus purpuratus, S. franciscanus. Total counts for sea urchins on 4 scrub brushes collected weekly in California; areas are arranged from north to south: WP: Westport; PC: Point Cabrillo; AC: Arena Cove Pier; GV: Gaviota Pier; EP: Ellwood Pier; SW: Stearn's Wharf; DP: Dana Point; SI: Scnpps Institution of Oceanography Pier; OB: Ocean Beach Pier; PL: Point Loma

\begin{tabular}{|c|c|c|c|c|c|c|c|c|c|c|}
\hline \multirow[t]{2}{*}{ Year } & \multicolumn{10}{|c|}{ Area } \\
\hline & WP & $P C$ & $\mathrm{AC}$ & GV & $E P$ & SW & $\mathrm{DP}$ & SI & $\mathrm{OB}$ & PL \\
\hline \multicolumn{11}{|c|}{ S. purpuratus } \\
\hline 1990 & 0 & 0 & 0 & & 19 & & 22 & 258 & 31 & 19 \\
\hline 1991 & 2 & 28 & 0 & 596 & 30 & 107 & 20 & 102 & 11 & 103.5 \\
\hline 1992 & 53 & 190 & & 355 & 24 & 41 & 18 & 67 & 25 & 58 \\
\hline 1993 & 0 & 282 & & 32 & 1 & 13 & 6 & 21 & 4 & \\
\hline Mean & 13.7 & 125 & 0 & 327.7 & 18.5 & 53.7 & 16.5 & 112 & 17.8 & 60.2 \\
\hline SD & 26.2 & 134 & & 283.0 & 12.5 & 48.3 & 7.2 & 102.8 & 12.4 & 42.3 \\
\hline $\mathrm{CV} \%$ & 190 & 107 & & 86 & 68 & 90 & 44 & 92 & 70 & 70 \\
\hline \multicolumn{11}{|c|}{ S. franciscanus } \\
\hline 1990 & 0 & 3 & 1 & & 1 & & 33 & 17 & 0 & 6 \\
\hline 1991 & 0 & 0 & 0 & 100 & 14 & 21 & 21 & 13 & 0 & 32.5 \\
\hline 1992 & 5 & 38 & & 19 & 6 & 5 & 9 & 16 & 2 & 9 \\
\hline 1993 & 0 & 8 & & 0 & 0 & 1 & 0 & 0 & 0 & \\
\hline Mean & 1.3 & 12.3 & 0.5 & 39.7 & 5.2 & 9.0 & 15.8 & 11.5 & 0.5 & 15.8 \\
\hline SD & 2.5 & 17.5 & & 53.1 & 6.4 & 10.6 & 14.4 & 7.9 & 1.0 & 14.5 \\
\hline CV\% & 200 & 143 & & 134 & 122 & 118 & 91 & 68 & 200 & 92 \\
\hline
\end{tabular}

1994). Some of the effects of El Niño in California are reduced southeast transport by the California Current, decreased intensity and frequency of coastal upwelling, and increased onshore transport (Chelton 1981, Simpson 1984a, b). Roughgarden et al. (1988) demonstrated that barnacle larvae tended to be farther offshore following periods of strong upwelling in central California and that there was a striking negative correlation between the mean unwelling index from January to June and the average annual recruitment rate.

Hobson \& Chess (1988) provide evidence for offshore transport of gelatinous zooplankton during periods of upwelling on the Mendocino coast near our study sites. They also found that shoreward transport occurred not only during periods of southerly winds that caused downwelling but also during periods of calm when

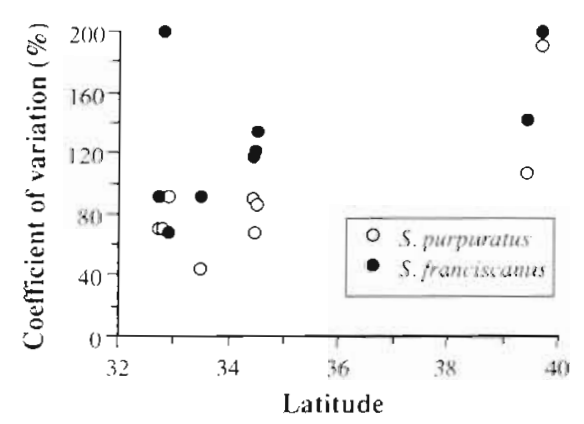

Fig. 9. Strongylocentrotus purpuratus, S. franciscanus. Coefficlent of variation of annual settlement versus location; northern sites generally were more variable than southern sites upwelling broke down. Although our observations in northern California are consistent with the hypothesis that settlement is increased during El Niño years due to reduced upwelling, variation in settlement we observed within the Southern California Bight cannot be explained in a similar manner. There was little difference in the intensity of settlement in 1990 to 1991 and 1992 to 1993 at Ocean Beach and Point Loma, but there was a trend toward less settlement during El Niño at all other sites, especially Scripps Pier and Gaviota Pier. Recruitment of purple sea urchins has

Table 2. Strongylocentrotus purpuratus, S. franciscanus. Twoway ANOVA comparing the coefficient of variation (CV) in annual settlement between species and between locations, north and south of Point Conception, without interaction. $\mathrm{n}=18 ; \mathrm{R}^{2}=0.52$

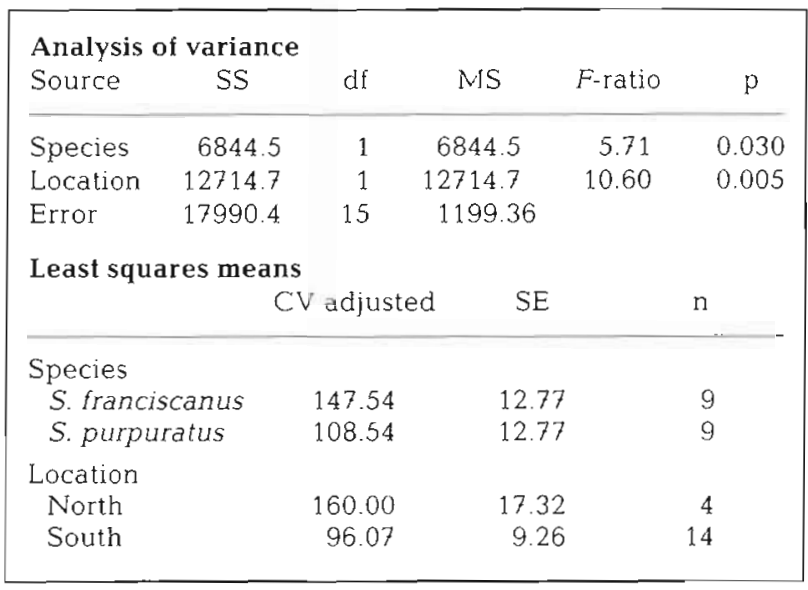


been positively correlated with upwelling at San Diego from 1969 to 1977 and the unusual settlement of this species at Sunset Bay, Oregon, in 1963 was during a season of unusually weak cross-shelf water movement (Ebert 1983), so the inverse pattern of settlement between northern and southern California does not appear to be an artifact of the 1990 to 1993 settlement seasons. It may be that when oceanographic conditions in the north are favorable for settlement, the opposite condition exists in the south.

In general, winter-spring is the period of maximum spawning potential for Strongylocentrotus purpuratus both north and south of Point Conception (Lasker \& Giese 1954, Bennett \& Giese 1955. MacGinite \& MacGinite 1968, Gonor 1973, Pearse 1981, Harlberg et al. 1987, Strathmann 1987). S. franciscanus is similar to $S$. purpuratus in having a winter-spring season in southern California; however, north of Point Conception, the potential season shifts to later in spring and summer with increasing latitude (Johnson 1930, Greenfield et al. 1958, MacGinite \& MacGinite 1968, Baker 1973, Gonor 1973, Kramer \& Nordin 1975, Bernard 1977, Pearse 1981, Strathmann 1987). Given the suggested spawning seasons, the settlers we observed in the fall and winter at sites in southern California raise an interesting question. Were they produced by relatively short-lived larvae ( 1 to $3 \mathrm{mo}$ ), or much older larvae that were spawned during the previous winter 9 to 11 mo earlier? Harrold et al. (1991) raised a similar question concerning sea urchin settlement in Monterey Bay at times that seemed inappropriate for the presumed times of spawning. A possible resolution of the puzzle would be to examine accumulation of 'aging pigments' (Young 1982, Nicol 1987, Hill \& Wormsley 1991) in newly settled animals. If new settlers showed increases in aging pigment concentrations from spring to fall, then it would be strong evidence that they had been spawned in winter and had, indeed, spent may months in the plankton

\section{Strongylocentrotus purpuratus}

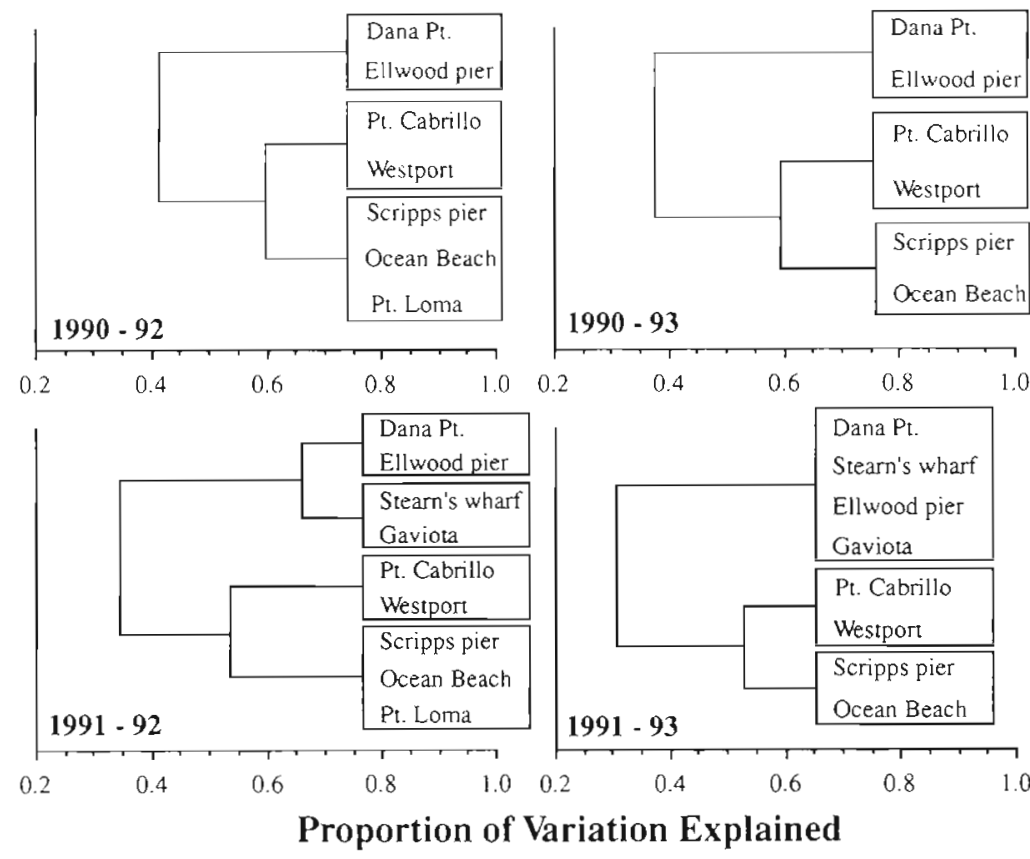

Fig. 10. Strongylocentrotus purpuratus. Principal component clustering analysis (Procedure VARCLUS, SAS Institute 1988) for settlement of purple sea urchins at sites along the California coast using 4 different time periods

\section{Strongylocentrotus franciscanus}

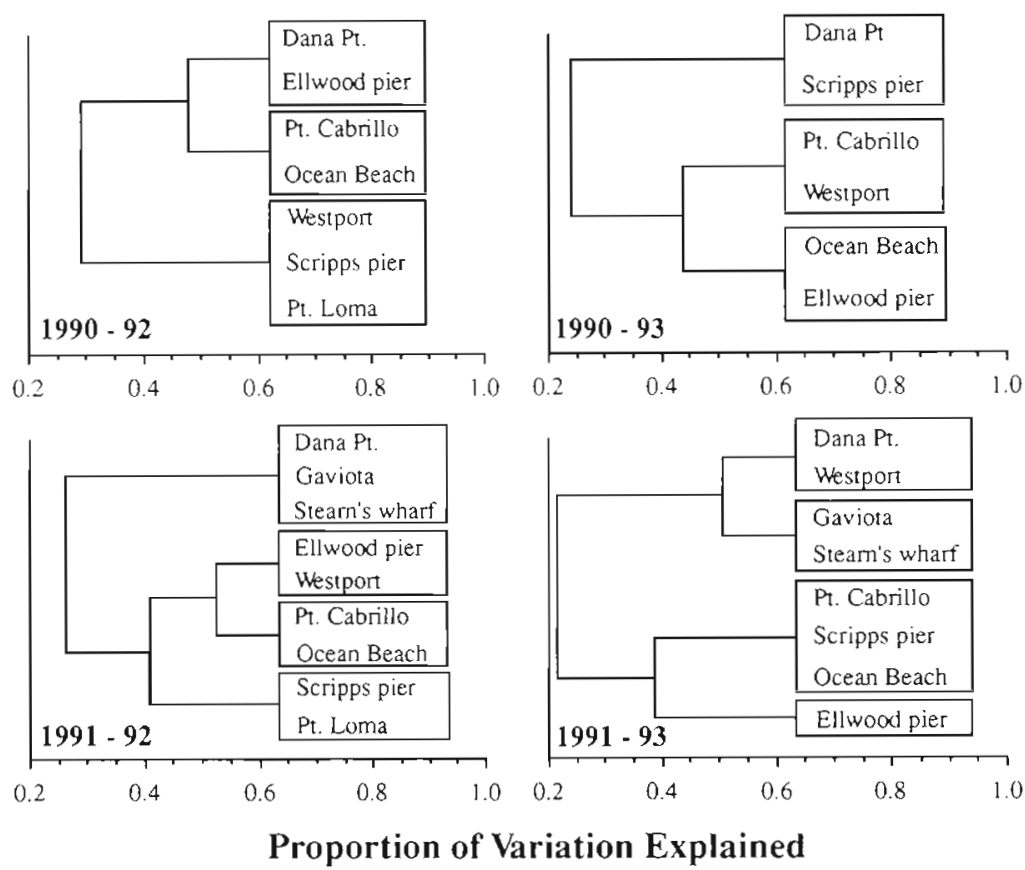

Fig. 11. Strongylocentrotus franciscanus. Principal component clustering analysis for settlement of red sea urchins at sites along the California coast using 4 different time periods 
Determining linkages among populations might be done from water-mass signatures using elemental analysis of skeletal parts of settlers that would point to areas where early development took place. Remnants of arm spicules that develop during the first week after fertilization are incorporated into the plates of the apical system at metamorphosis (illustrated in Emlet 1985) and so are a record of spawning origin. Analysis should be possible similar to that applied to determining the areas of origin of fish from elemental composition of otoliths (e.g. Lapi \& Mulligan 1981, Mulligan et al. 1987)

Model construction for metapopulations of marine species such as Strongylocentrotus franciscanus and $S$. purpuratus must have a strong component of physical oceanography in order to understand how larvae can be moved from the sites of spawning to the sites of settlement. However, we also wish to emphasize that some questions might be answered only by attempting to 'ask' the animals how long they have traveled and where they came from. The fact that both $S$. franciscanus and $S$. purpuratus are longlived species (Ebert 1975, Russell 1987, Ebert \& Russell 1993) suggests that important events in the life cycle may occur very infrequently (cf. Ebert 1983) and so long-term and large-scale studies are needed in order to observe those unusual events that may be most important to the evolution of their life histories.

Acknowledgements. This work was supported by funds from a self-imposed landing tax from the sea urchin fishermen of California that were awarded by the Directors Sea Urchin Advisory Committee of the California Department of Fish and Game. Additional funds were provided by the Pacific States Fishery Commission and, for a part of 1992, from California Sea Grant. Tending of collectors in northern California was done by I. Tanaguchi, J. Mello, and J. Hendrix of the California Department of Fish and Game. J. Richards of California Sea Grant supervised tending of collectors at Gaviota Pier, Ellwood Pier, and Stearn's Wharf by W. James, E. Johnson, N. Adams, J Navarro, and A. Morris. A. Wenner provided laboratory space at U.C. Santa Barbara and M. Page provided general assistance. Collectors at Ellwood pier also were tended by S. Swarbrick and D. Lohse of U.C. Santa Barbara. $\mathrm{H}$. Helling of the Orange County Marine Institute supervised the tending of brushes at Dana Point by J. Smith, B. Paschal, A. Balcar, and A. Shimizu. R. Day, a sea urchin fisherman from San Clemente, helped to maintain the collectors in the field. Collectors off Point Loma were tended by a variety of volunteers: D. Rudie, a sea urchin processor (Catalina Offshore Products), and P. Halmay, G. McConnell, M. Hobron and $M$. Buxton, sea urchin fishermen from San Diego; $S$. Cassell, T Delle, D. McKay, K. Ulrich, M. Otjens, D. Glantz, and R. McPeak of Kelco (a Division of Merk Inc.); and J. Rankin and H. Dorr, biology teachers from Mt Carmel High School. Processing of samples in southern California was done by D. Medeiros and J. Wolf of San Diego State University. K. Zabloudil and B. Harris of EcoSystems Management provided many hours for the maintenance of sonicators. This work would not have been possible without substantial contributions of time. We sincerely appreciate all of the support we have received.

\section{LITERATURE CITED}

Bak, R. P. M. (1985). Recruitment patterns and mass mortalities in the sea urchin Diadema antillarum. Proc. Sth int. coral Reef Conf. 5: 267-272

Baker, S. L. (1973). Growth of the red sea urchin Strongylocentrotus franciscanus (Agassiz) in two natural habitats. M.Sc. thesis, San Diego State University

Bennett, J., Giese, A. C. (1955). The annual reproductive cycles in two western sea urchins. Biol. Bull. 109: 226-237

Bernard, F. R. (1977). Fishery and reproductive cycle of the red sea urchin, Strongylocentrotus franciscanus, in British Columbia. J. Fish. Res. Bd Can. 34: 604-610

Bernard, F. R., Miller, D. C. (1973). Preliminary investigation on the red sea urchin resources of British Columbia [Strongylocentrotus franciscanus (Agassiz)]. Fish. Res. Bd Can, Tech. Rep. 400

Botsford, L. W. (1992). Individual state structure in population models. In: DeAngelis, D. L., Gross, L. J. (eds.) Individualbased models and approaches in ecology. Chapman \& Hall, New York, p. 213-236

Cameron, R. A., Schroeter, S. C. (1980). Sea urchin recruitment: effect of substrate selection on juvenile distribution. Mar. Ecol. Prog. Ser. 2: 243-247

Chelton, D. B. (1981). Interannual variability of the California Current - physical factors. Calif. Coop. Ocean Fish. Invest. Rep. 22: $34-48$

Dept of Mariculture, Hokkaido Central Fisheries Experiment Station (1984). On the natural seeds collection, intermediate culture and release of the sea urchin, Strongylocentrotus intermedius. J. Hokkaidō Fish. Exp. Stat. 41 270-315 Transl. (extended summary). Madelon Mottet, Jpn. Sci. Liaison, 595 Tucker Ave., No. 39, Friday Harbor WA 98250, USA

Ebert, T. A. (1968). Growth rates of the sea urchin Strongylocentrotus purpuratus related to food availability and spine abrasion. Ecology 49: 1075-1091

Ebert, T. A. (1975). Growth and mortality of post-larval echinoids. Am. Zool. 15: 755-775

Ebert, T. A. (1983). Recruitment in echinoderms. In: Jangoux, M., Lawrence, J. M. (eds.) Echinoderm studies, Vol. 1. A. A. Balkema, Rotterdam, p. 169-203

Ebert, T. A., Russell, M. P. (1988). Latitudinal variation in size structure of the west coast purple sea urchin: a correlation with headlands. Limnol. Oceanogr. 32: 286-294

Ebert, T A., Russell, M. P. (1993). Growth and mortality of subtidal red sea urchins (Strongylocentrotus franciscanus) at San Nicolas Island, California, USA: problems with models. Mar. Biol. 117: 79-89

Ebert, T A., Schroeter, S. C., Dixon, J. D. (1991). Studies of feasibility of sea urchin enhancement in California. Final Tech. Rep. FG9310, California Department of Fish and Game, Sacramento, CA. p. 1-21

Emlet, R. B. (1985). Crystal axes in recent and fossil adult echinoids indicate trophic mode in larval development. Science 230: $937-940$

Gonor, J. J. (1973). Reproductive cycles in Oregon populations of the echinoid, Strongylocentrotus purpuratus (Stimpson). I. Annual gonad growth and ovarian gametogenic cycles. J. exp. mar. Biol. Ecol. 12: 45-64

Greenfield, L., Giese, A. C., Farmanfarmaian, A., Boolootian, 
R. A. (1958). Cyclic biochemical changes in several echinoderms. J. exp. Zool. 139: 507-527

Halliwell, G. R., Allen, J. S. (1987). The large-scale coastal wind field along the west coast of North America, 1981-1982. J. geophys. Res. 92: 1861-1884

Harlberg, F., Shankaraiah, K, Giese, A. C., Halberg, F. (1987). The chronobiology of marine invertebrates: methods of analysis. In: Giese, A. C., Pearse, J. S., Pearse, V. B. (eds.) Reproduction of marine invertebrates, Vol. IX, General aspects: seeking unity in diversity. Boxwood Press, Pacific Grove, CA, p. 331-384

Harrold, C., Lisin, S., Light, K. H., Tudor, S. (1991). Isolating settlement from recruitment of sea urchins. J. exp. mar Biol. Ecol. 147: 81-94

Hayward, T L. (1994). Preliminary observations of the 1991-1992 El Niño in the California Current. Calif. Coop. Ocean Fish. Invest. Rep. (in press)

Hill, K. T., Womersley, C. (1991). Critical aspects of fluorescent age-pigment methodologies: modification for accurate analysis and age assessments in aquatic organisms. Mar. Biol. 109: 1-11

Hobson, E. S., Chess, J. R. (1988). Trophic relations of the blue rockfish, Sebastes mystinus, in a coastal upwelling system off northern California. Fish. Bull. U.S. 86: 715-743

Huyer, A. E. (1983). Coastal upwelling in the California Current system. Prog. Oceanogr 12: 259-284

Johnson, M. W. (1930). Notes on the development of Strongylocentrotus franciscanus. Publ. Puget Sound Biol. Stn 7: $401-411$

Kosro, P. M., Huyer, A, Ramp, S. R., Smith, R. L., Chavez, F. P., Cowles, T J., Abbott, M. R., Strub, P. T., Barber, R. T., Jessen, P., Small, L. F. (1991). The structure of the transition zone between coastal waters and the open ocean off northern California, winter and spring 1987. J. geophys. Res. 96: 14707-14730

Kramer, D. E., Nordin, D. M. A. (1975). Physical data from a study of size, weight and gonad quality for the red sea urchin (Strongylocentrotus franciscanus (Agassiz)) over a one-year period. Fish. Res. Bd Can. MS Rep. Ser. 1372: $1-91$

Lapi, L. A., Mulligan, T. J. (1981). Salmon stock identification using a microanalytic technique to measure elements present in the freshwater growth region of scales. Can. J. Fish. Aquat. Sci. 38: 744-751

Lasker, R., Giese, A. C. (1954). Nutrition of the sea urchin Strongylocentrotus purpuratus. Biol. Bull. 106: 328-340

Leahy, P. S. (1986). Laboratory culture of Strongylocentrotus purpuratus adults, embryos, and larvae. Meth. Cell Biol. 27: $1-13$

Levins, R. (1969). Some demographic and genetic consequences of environmental heterogeneity for biological control. Bull. Ent. Soc. Am. 15: 237-240

Loosanoff, V L. (1964). Variation in time and intensity of setting of the starfish. Asterias forbesi, in Long Island Sound during a twenty-five year period. Biol. Bull. 126: $423-439$

Lynn, R. S., Simpson, J. J. (1987). The California Current system: the seasonal variability of its physical characteristics. J. geophys. Res. 92: 12947-12966

MacGinitie, G. E., MacGinitie, N. (1968). Natural history of marine animals, 2nd edn. McGraw-Hill Book Co., San Francisco

Mackas, D., Strub, T., Hunter, J. (eds.) (1992). Report on climate change and the California Current ecosystem, Eastern Boundary Current Program, U.S. GLOBEC, Global Ocean Ecosystems Dynamics, Rep. 7. Scientific Steering Committee Coordinating Office, Univ. of Calif., Davis
Morris, R. H., Abbott, D. P., Haderlie, E. C. (1980). Intertidal invertebrates of California. Stanford University Press, Stanford

Mulligan, T J., Martin, F. D., Smucker, R. A., Wright, D. A. (1987). A method of stock identification based on the elemental composition of striped bass Morone saxatilis (Walbaum) otoliths. J. exp. mar. Biol. Ecol. 114: 241-248

Nicol, S. (1987). Some limitations on the use of the lipofuscin ageing technique. Mar. Biol. 93: 609-614

Owen, R. W. (1980). Eddies of the California Current system: physical and ecological characteristics. In: Power, D. M. (ed.) The California islands. Santa Barbara Museum of Natural History, Santa Barbara, p. 237-263

Paine, R. T (1986). Benthic community - water column coupling during the 1982-1983 El Niño. Are community changes at high latitudes attributable to cause or coincidence? Limnol. Oceanogr. 31: 351-360

Parrish, R. H., Nelson, C. S., Bakun, A. (1981). Transport mechanisms and reproductive success of fishes in the California current. Biol. Oceanogr, 1. 175-203

Pearse, J. S. (1981). Synchronization of gametogenesis in the sea urchins Strongylocentrotus purpuratus and S. franciscanus. In: Clark, E. H. Jr, Adams, T. S. (eds.) Advances in invertebrate reproduction. Elsevier, Amsterdam, p. $53-68$

Pearse, J. S., Clark, M. E., Leighton, D. L., Mitchell, C. T., North, W. J. (1970). Final report, Marine waste disposal and sea urchins ecology, Appendix. In: North, W. J. (ed.) Kelp habitat improvement project. Annual Report, 1 July 1969 - 30 June 1970. W. M. Keck Laboratory of Environmental Health Engineering, California Institute of Technology, Pasadena, p. 1-93

Pearse, J. S., Hines, A. H. (1987). Long-term population dynamics of sea urchins in a central California kelp forest: rare recruitment and rapid decline. Mar. Ecol. Prog. Ser. 39: $275-283$

Roughgarden, J., Gaines, S., Possingham, H. (1988). Recruitment dynamics in complex life cycles. Science 241: $1460-1466$

Rowley, R. J. (1989). Settlement and recruitment of sea urchins (Strongylocentrotus spp.) in a sea-urchin barren ground and a kelp bed: are populations regulated by settlement or post-settlement processes? Mar. Biol. 100: 485-494

Russell, M. P. (1987). Life history traits and resource allocation. in the purple sea urchin Strongylocentrotus purpuratus (Stimpson). J. exp. mar. Biol. Ecol. 108: 199-216

SAS Institute (1988). SAS/STAT Users guide, Release 6.03 edition. SAS Institute, Inc., Cary, NC

Scheltema, R. S. (1971). Larval dispersal as a means of genetic exchange between geographically separated populations of shallow-water benthic marine gastropods. Biol. Bull. 140: $284-322$

Scheltema, R. S. (1986). On dispersal and planktonic larvae of benthic invertebrates: an eclectic overview and summary of problems. Bull. mar. Sci. 39: 290-322

Seapy, R. R., Littler, M. M. (1980). Biogeography of rocky intertidal macroinvertebrates of the southern California islands. In: Power, D. M. (ed.) The California islands; proceedings of a multidisciplinary symposium. Santa Barbara Museum of Natural History, Santa Barbara, p. 307-323

Simpson, J. J. (1984a). El Niño-induced onshore transport in the California Current during 1982-1983. Geophys. Res. Lett. 11: 233-236

Simpson, J. J. (1984b). A simple model of the 1982-83 California 'El Niño' Geophys. Res. Lett. 11: 243-246

Sloan, N. A., Lauridsen, C. P., Harbo, R. M. (1987). Recruit- 
ment characteristics of the commercially harvested red sea urchin Strongylocentrotus franciscanus in Southern British Columbia, Canada. Fish. Res. 5: 55-69

Strathmann, M. (1987). Reproduction and development of marine invertebrates of the northern Pacific coast. Univ, of Washington Press, Seattle

Strathmann, R. (1978). Length of pelagic period in echinoderms with feeding larvae from the northeast Pacific J. exp. mar. Biol. Ecol. 34: 23-27

Tegner, M. J. (1989). The feasibility of enhancing red sea urchin, Strongylocentrotus franciscanus, stocks in Cali-

This article was submitted to the editor fornia: an analysis of the options. Mar. Fish. Rev. 51: 1-22 Tegner, M. J., Dayton, P. K. (1981). Population structure, recruitment and mortality of two sea urchins (Strongylocentrotus franciscanus and $S$. purpuratus) in a kelp forest. Mar. Ecol. Prog. Ser. 5: 255-268

Thomas, A. C., Strub, P. I (1990). Seasonal and interannual variability of phytoplankton pigment concentrations across a California Current system frontal zone. J geophys. Res. 95: 13023-13042

Young, R. G. (1982). Fluorescent age pigment in insect lysosomes. Exp. Gerontol. 17: 1-6

Manuscript first received: November 2, 1993 Revised version accepted: May 2, 1994 